\title{
Corporate Social Responsibility from the Viewpoint of Social Risk
}

\author{
Maria Teresa Bosch-Badia, Joan Montllor-Serrats, Maria Antonia Tarrazon-Rodon \\ Department of Business, Universitat Autonoma de Barcelona, Bellaterra, Spain \\ Email: Joan.Montllor@uab.cat
}

Received 19 July 2014; revised 11 August 2014; accepted 9 September 2014

Copyright (C) 2014 by authors and Scientific Research Publishing Inc.

This work is licensed under the Creative Commons Attribution International License (CC BY).

http://creativecommons.org/licenses/by/4.0/

(c) (i) Open Access

\section{Abstract}

This paper studies Corporate Social Responsibility (CSR) from the viewpoint of social risk as part of reputational risk. We adopt the conception of social risk that includes the risks originated by environmental and social sustainability. Any risk involves hazards and opportunities. The success of its management consists of hedging the hazards and turning opportunities into value. CSR is the key for dealing with both goals. Opportunities can be identified through an accurate analysis that leads to discovering the unsatisfied needs contained in societal claims in general and in the private politics of Non Governmental Organizations (NGO) in particular. Bringing these opportunities into line with the corporate know-how and undertaking projects together with the stakeholders with whom synergy is possible enables corporations to create shared value. A direct hedging of social risk hazards is hardly impossible. A good corporate social image constitutes a sound hedging against social risk. We have associated to social image the concept of CSR capital which means the value created through CSR. On this basis, we analyze the meaning and implications of social failure using Leland's bankruptcy costs model. The quantification of the CSR capital may parallel the quantification of reputational capital about which several papers have been published. Combining the direct net present value created by a CSR expense with its tax savings and the savings it produces in the present value of the social failure costs, we estimate the total net present value created by these expenses. The analysis of social failure costs and the value created by social expenses is accompanied by a numerical illustration.

\section{Keywords}

Corporate Social Responsibility, Social Risk, Corporate Reputation, Corporate Social Image 


\section{Introduction}

In this paper ${ }^{1}$ we analyze Corporate Social Responsibility (CSR) from the viewpoint of social risk. CSR has been studied from different approaches, but scarcely from the risk side, although social risk is often quoted in CSR literature. Risk pervades all corporate activities. It is a source of hazard, but at the same time, a source of new opportunities. Bernstein ([1] p. 8) states that the word "risk" derives from the early Italian risicare, which means "to dare". In this sense, risk is a choice rather than a fate. The actions we dare to take, which depend on how free we are to make choices, are what the story of risk is all about. And that story helps define what it means to be a human being. The contemporary globalized world obviously faces the hazards of global warming and the globalization effects on human rights. These risks are closely related to the activities of multinational corporations, and, thus, are especially relevant for CSR. United Nations (UN) recognize their relevance by promoting the Global Compact project [2] defined as a strategic policy initiative for businesses that are committed to aligning their operations and strategies with ten universally accepted principles in the areas of human rights, labour, environment and anti-corruption. The Ruggie reports, i.e. the reports of the UN Special Representative on Transnational Corporations and Human Rights, which started in 2008, have lead to the UN Guiding Principles of Business and Human Rights [3]. The implications of Ruggie reports for CSR have been studied by McCorquodale [4].

On this basis, it can be said that CSR is clearly linked to the risk due to environmental and social issues and, of course, to facing and managing it with ethics: as Lee and Lee ([5] p.) xii have said, because globalization is really about people it is ultimately about ethics. The questions that we aim to answer in this paper are: What does the risk of CSR consists of? How can it be managed? Is hedging of CSR risk possible? Can we find a situation equivalent to bankruptcy in the CSR side? The article is organized as follows. In the Second Section we study the nature of reputational and social risks and the links between them. The Third Section is devoted to the management of social risk and the importance for corporations of building up a CSR capital as the economic equivalent of a sound social image. In the Fourth Section we develop an analytical model about the costs of social failure and the valuation of CSR expenses. The Fifth Section closes the paper.

\section{Reputational Risk and Social Risk}

Reputational risk and social risk are closely linked, having the former a broader meaning than the latter which, in fact, is a part of it. The concept of corporate reputation expresses the trust that the corporation deserves in both the real and the financial markets and, especially, among its stakeholders. Credit Suisse [6] defines reputational risk as the damage of our standing in the market. Soprano, Crielaard, Piacenza and Ruspatini [7] state that the key element of reputational risk is the impact of an specific event that could worsen, or affect negatively, the perception of a company's reliability, of its services "quality", its management fairness, or, more generally, its truth worthiness. According to these authors (p. 160) reputational risk is comprehensive for market risk, credit risk, liquidity risk, operational risk and any other risk that can impact on corporate reputation. Stansfield ([8] p. 471) signals that corporate reputation is the outcome of interweaving and blending financial performance and strength, client trust and confidence, corporate social responsibility, corporate governance practices, corporate ethics, corporate disclosure practices, as well as relations with regulatory authorities and compliance in a broad sense. Stansfield refers to financial institutions, but it is quite clear that this sentence has a broader meaning. Social risk can be regarded as the part of reputational risk due to environmental and social issues, since both have a direct impact on society. Bekefi, Jenkins and Kytle [9] define it as challenges by stakeholders to companies' business practices due to real or perceived business impacts on a broad range of issues related to human welfare-for example, working conditions, environmental quality, health or economic opportunity. These challenges are directly connected with the good or bad reputation the corporation under consideration has in society. A good social image is an important asset for any corporation. Having this image substantially damaged forces the corporation to assume the cost of refurbishing it. This hazard is one of the main threads of reputational risk and, thus, of social risk. At the same time, social risk means that the concerns that society has with respect to corporate behaviour bring the opportunity of building a good public social image that leads stakeholders and society in general to trust the corporation. Orlitzky and Benjamin [10] point out that reputation for social responsibility is central in terms of risk. Linking social risk to financial risk, they conclude that the higher the corporate social performance, the lower the corporate financial risk.

\footnotetext{
${ }^{1}$ The authors thank an anonymous referee for helpful comments. The usual disclaimer applies.
} 
A corporate responsible behaviour means to make decisions and to perform by respecting and fostering the three pillars of sustainability: environmental, social and financial. The latter constitutes the central interest of shareholders. The concernment about environmental and social responsibility goes beyond shareholders because it belongs to the society as a whole, although some facets of social sustainability are of interest of corporate workers in particular. In fact, CSR consists of the actions that corporations undertake in order to follow an environmentally and socially sustainable strategy and policy and to have them acknowledged by society. Societal claims for environmental and social sustainability have been in the roots of CSR. The assumption of the essence of these claims by stakeholders and corporations themselves has lead to the growing importance of social risk and CSR. Private politics, i.e. the activities of Non Governmental Organizations (NGO) and similar associations, is a source of social risks because through its claims and the way of presenting them the corporate social image may be jeopardised. Baron [11] defines private politics as the action through which an activist seeks to change the production practices of a firm for the purpose of redistribution to those whose interests it supports. He also points out that private politics may change the competitive positions of firms in an industry. Schepers [12] analyses the impact of NGO in multinationals, distinguishing the kind of interests NGO serve according to the nature and geographical location, North vs. South, of their supporters. Changes in public regulation and the costs they may entail, especially in production processes, also are an effect of social risk that corporation can anticipate and hedge through CSR actions as Kitzmueller and Shimshack [13] say. NGO are, in turn, also subject to social risk and to their own social responsibility. Social image and social trust are even more relevant for them. At the end of Section 3 we briefly summarize some relevant papers that relate CSR with social risk from the hedging viewpoint.

The worst outcome of financial risk is bankruptcy. We can define a parallel, although of minor impact, for social risk: the corporate social failure. It consists of the situation in which the corporation, due to a set of hazards or to a single hazard of high impact, has its social image completely damaged and is forced to undertake a course of action to refurbish it. Social failure is expected to have a negative impact on shares value equal at least to the cost of refurbishing the corporate social image. Below we develop an analytical model of it.

\section{The Management of Social Risk: Building up a CSR Capital}

Any risk needs to be managed. As Bernstein ([1], p. 197), states: the essence of risk management lies in maximizing the areas where we have some control over the outcome while minimizing the areas where we have absolutely no control over the outcome and the linkage between effect and cause is hidden from us. Some risks can be hedged by taking positions in other assets that compensate their volatility. Nevertheless, for this to become possible, the risk should correspond to an asset traded in the market and, preferably, to be the underlying asset of some derivatives contracts, as it is the case of many commodities and financial assets. Social risk is closely associated to the corporate production techniques and the relationships between the corporation and its workers, suppliers and customers. For these reasons, the management of social risk needs to become part of the corporate strategy, which leads to CSR. Baron, [11] and [14], states that the true, i.e. sheer, CSR should be the outcome of moral management with an altruistic aim, instead of a self-interest approach to social topics that he denominates strategic CSR. Sheer CSR regards its expenses as a social dividend. From the perspective of risk, both approaches cannot be regarded incompatible one each other. Since social risk exists, it needs to be managed and integrated into corporate strategy with the aim to create value and to undertake CSR projects financially sustainable by themselves. Nevertheless, strategic CSR does not prevent the corporation from undertaking purely altruistic initiatives that will contribute positively to the corporate social image and, therefore to the hedging of social risk. In practice, the frontier between both approaches is often fuzzy.

Strategic CSR can be approached according to two different criteria: expense and opportunity. The expense criterium regards CSR as a pure expense. It leads to spend on CSR until the marginal cost of it equates the marginal financial value that would have been destroyed without CSR. It obeys to a static conception of the economy. The opportunity criterium consists of considering social claims for CSR as an unsatisfied need, namely a potential demand that can be turned into an effective demand by showing to society what the corporation can do for environmental and social sustainability. Bekefi and Epstein [15] develop a model for the transformation of social and environmental risk into opportunities and for bringing them into line with corporate strategy. The concept of shared value coined by Porter and Kramer [16], after the works by Porter and Van der Linde [17] about sustainability as a source of innovation and Porter and Kramer [18] about the integration between business and society, substitutes giving by sharing. Corporations are regarded as the kernels of value creation, but not 
only focused on themselves, but sharing their know-how with their stakeholders. As Porter and Kramer ([16], p. 4), state shared value involves creating economic value for society by addressing its needs and challenges... reconnect company success with social progress. Pfitzer, Bocksette and Stamp ([19], p. 9), identify five ingredients to create shared value: social purpose, a defined need, measurement, the right innovation structure, and co-creation. The shared value approach, adopted now by a remarkable number of corporations (www.fsg.org), goes beyond the hedging of social risk by integrating social demands into corporations. Porter and Kramer ([16], p. 5), implicitly incorporate into shared value the control of social risk by identifying and satisfying the demands embedded in it: shared value recognizes that societal needs, not just conventional economic needs define markets. It also recognizes that social harms or weaknesses frequently create internal costs for firms. Of course, CSR needs to be accompanied of a very good communication policy to the real market and to the financial market as well. Both markets must become aware of the value added to products and to shares by CSR in order to make financially sustainable the environmentally and socially sustainable lines undertaken by the corporation.

In fact, a sound management of CSR goes beyond social claims themselves. The corporation analyses the environmental and social challenges it faces, studies what to do in order to overcome them and develops the adequate courses of action by undertaking the appropriate investment projects. In this process, some needs, and thus opportunities, not contained in the social claims may be identified. For a good management of social risk in the long run it is central a correct identification of the environmental and social needs that the corporation has the opportunity to satisfy and how it can do it. It means to enter into the link that leads from strategy to capital budgeting. As Baron [14] has pointed out, the social claims for sustainability introduce a new market, the market for social pressure, and, thus, any corporation has to deal with three markets: the product market, the financial market and the market for social pressure. Kitzmueller and Shimshack [13] also analyze the relationship between CSR and the labour market. Managers have to design the courses of action they undertake with these markets in mind. CSR is an especially sensitive topic in this respect because it has to fulfil their expectations. The risk of coordination is obvious and relevant. The CSR strategy must not only be coherent in itself but, at the same time, must be accepted in both the product and the financial market. Some sustainability decisions involve important investments that must be financially sustainable at the same time. In this respect, the social acceptance of CSR, especially in prices and selecting the products of socially responsible corporations, is no less central. Society, in turn, is responsible for transforming its claims into real demand. Investment expenses are, therefore, central for the management of social risk. Philanthropic expenses, in turn, can be regarded as a good collateral that may positively contribute to the communication side of CSR, especially if they are related to the corporate know-how as pointed out by Porter and Kramer [20].

All in all, social risk requires a sophisticated and long run approach which involves, at the same time, the risk associated to its investment projects. Although no specific hedging is possible, the social image of a socially responsible corporation constitutes a guarantee for facing any negative hazard on the sustainability side. Kitzmueller and Shimshack ([13], p. 66), state about CSR as a hedge for social risk that the logic is comparable to hedging against future risk in financial markets, just here the firm insures itself against a potential campaign by an activist or regulatory action taken by a government. Godfrey, Merrill and Hansen [21] study the insurance effect with respect to social risk provided by CSR. Gaultier-Gaillard and Louisot [22] study the competitive advantage that reputations create for insurance companies, a sector in which the public trust in corporations is essential. At the same time, they analyze the relevance of corporate governance in this respect by contrasting a closed management system with an open one. Fombrun, Gardberg and Barred [23] and Fombrun [24] have conducted empirical analysis that show the importance that managers attribute to having built up a reputational capital because it constitutes a hedge against reputational hazards. Bemabou and Tirole [25] underline the importance of social image: prosocial behaviours cannot be understood if one ignores image concerns. According to them, CSR introduces a long term perspective in corporate strategy that leads to maximize intertemporal profits and contributes to put aside the short term bias often observed in corporate management. On this basis, we can say that CSR can be regarded as a hedging against short termism.

Summing up, and following the Bernstein's sentence quoted at the beginning of this Section, since social risk unavoidably involves unexpected environmental and even social hazards beyond the control of the corporation, the best hedging against it consists of implementing a sound CSR strategy centred on the strong points through which the corporation can create shared value. In this way, a positive social image and its associated CSR Capital are built up. Not just a social image that is admired, but one that is rooted in stakeholders' convictions and interests and also well linked to society in general. 


\section{CSR Capital and Social Failure: An Analytical Model}

Next, we develop an analytical model with the aim of relating the main variables involved in social failure. The variables of this model are the CSR Capital $(S)$, its critical value $\left(S_{c r}\right)$, the cost of refurbishing the social image $\left(S^{*}\right)$, the volatility of the CSR Capital $(\sigma)$ and the risk free interest rate.

The quantification of reputational variables like these is no immediate and, in addition, it is beyond the scope of this work. Nevertheless, some remarkable attempts have been made. Srivastava, Mcinish, Wood and Capraro [26] have studied the relationship between reputation scores and the value of common stocks. Ponzi, Fombrun and Gardberg [27] have developed a model to measure corporate reputation. Bekefi and Epstein [28] have built up a method for incorporating the impact of social and political risk into investment analysis. Soprano, Crielaard, Piacenza and Ruspatini [7] study the measurement of reputational risk and present a method for the calculation of Reputational-Capital-at-Risk, similar to Value-at-Risk, which connects reputational risks to common stocks volatility. We define the CSR Capital as the market value of the present social image the corporation has. If the value of the CSR Capital falls under a critical amount, it is necessary to refurbish the corporate social image paying a certain amount. This is the scenario that we denominate social failure. We modelize it by applying an Arrow-Debreu security following a similar formulation than the one used by Leland [31] to express the present value of bankruptcy costs. Thus, the model we propose is subject to the same assumptions than Leland's, but referred to social risk. Asset's value, in our case the CSR capital, is supposed to follow a geometric Brownian motion. This stochastic process is compatible with the market efficiency hypothesis, i.e. which assets fairly valued. The Arrow-Debreu security is a derivative that pays $\$ 1$ if the asset equates a specific price and zero otherwise ${ }^{2}$. In Leland's model, the expression that stands for a security that pays $\$ 1$ if the corporate value $(V)$ equates the value at which shareholders decide to go bankrupt $\left(V_{B}\right)$ and nothing in any other circumstance is $p_{B}=\left(V / V_{B}\right)^{-2 r / \sigma^{2}}$ ([28], p. 1219). Values under $V_{B}$ are irrelevant because bankruptcy has been declared before and, thus, are never reached for the non-bankrupt corporation. In our case, using the symbols we have introduced and designating by $r$ the risk free interest rate and by $\sigma$ the volatility of the CSR Capital, the value of the Arrow-Debreu security is:

$$
s f=\left(\frac{S}{S_{c r}}\right)^{\frac{-2 r}{\sigma^{2}}}
$$

On this basis, we can assimilate the risk of social failure to a short position in a number of Arrow-Debreu securities equal to $S^{*}$. Then, the present value of the social failure can be written as:

$$
S F=S^{*}\left(\frac{S}{S_{c r}}\right)^{\frac{-2 r}{\sigma^{2}}}
$$

We can observe that if $S$ equates $S_{c r}$, then $S F$ equates $S^{*}$. Let us denominate social risk ratio $(\varphi)$ the quotient $S F / S^{*}$ and safety social ratio $(\eta)$ the quotient $S / S_{c r}$. Then:

$$
\varphi=\eta^{\frac{-2 r}{\sigma^{2}}}
$$

where $\varphi \leq 1$ because the Arrow-Debreu security is exercised when the safety social ratio equates 1 , and, thus $\eta \geq 1$. Equation (3) expresses the proportion of the present value of the failure costs on its maximum value as a function of the proportion of the CSR capital on its minimum or critical value, i.e. the social risk ratio, $\varphi$, as a function of the safety social ratio, $\eta$. The greater the social capital with respect to its critical value, the greater the safety social ratio $(\eta)$ and, thus, the lower the social risk ratio $(\varphi)$. About the latter, we can say that, the lower the better. It is straightforward to show that the derivative of $\varphi$ with respect to $\eta$ is negative $\left(-\left(2 r \eta^{-1-\frac{2 r}{\sigma^{2}}} / \sigma^{2}\right)\right)$. In Table 1 and Figure 1 we present a numerical illustration of this model.

This result enables us to calculate the impact of CSR expenses on value creation. In fact, if the expense has value creation capacity it can be approached as an investment. Let us denote by $X$ the expense, by $\tau$ the

\footnotetext{
${ }^{2}$ About Arrow-Debreu pricing and their applicability to derivatives, see Danthine and Donaldson [29], chapter 8, and Tapiero [30].
} 
Table 1. Social risk ratio.

\begin{tabular}{ccccccccccc}
\hline$\sigma \eta$ & 0.05 & 0.1 & 0.15 & 0.2 & 0.25 & 0.3 & 0.4 & 0.5 & 1 \\
\hline 1 & 1 & 1 & 1 & 1 & 1 & 1 & 1 & 1 & 1 \\
1.25 & 0.0281 & 0.4096 & 0.6725 & 0.8000 & 0.8669 & 0.9056 & 0.9457 & 0.9649 & 0.9911 \\
1.5 & 0.0015 & 0.1975 & 0.4863 & 0.6667 & 0.7714 & 0.8351 & 0.9036 & 0.9372 & 0.9839 \\
1.75 & 0.0001 & 0.1066 & 0.3698 & 0.5714 & 0.6990 & 0.7798 & 0.8694 & 0.9144 & 0.9779 \\
2 & 0.0000 & 0.0625 & 0.2916 & 0.5000 & 0.6417 & 0.7349 & 0.8409 & 0.8950 & 0.9727 \\
2.25 & 0.0000 & 0.0390 & 0.2365 & 0.4444 & 0.5951 & 0.6974 & 0.8165 & 0.8783 & 0.9681 \\
2.5 & 0.0000 & 0.0256 & 0.1961 & 0.4000 & 0.5563 & 0.6655 & 0.7953 & 0.8636 & 0.9640 \\
2.75 & 0.0000 & 0.0175 & 0.1656 & 0.3636 & 0.5234 & 0.6379 & 0.7765 & 0.8506 & 0.9603 \\
3 & 0.0000 & 0.0123 & 0.1418 & 0.3333 & 0.4950 & 0.6137 & 0.7598 & 0.8388 & 0.9570 \\
10 & 0.0000 & 0.0001 & 0.0167 & 0.1000 & 0.2291 & 0.3594 & 0.5623 & 0.6918 & 0.9120 \\
\hline
\end{tabular}

This table shows the values of the social risk ratio $(\varphi)$ for a constant interest rate of $2 \%$, a volatility evolving from $5 \%$ to $100 \%$ and a safety social ratio $\eta$ from 1 (minimum value) to 10 .
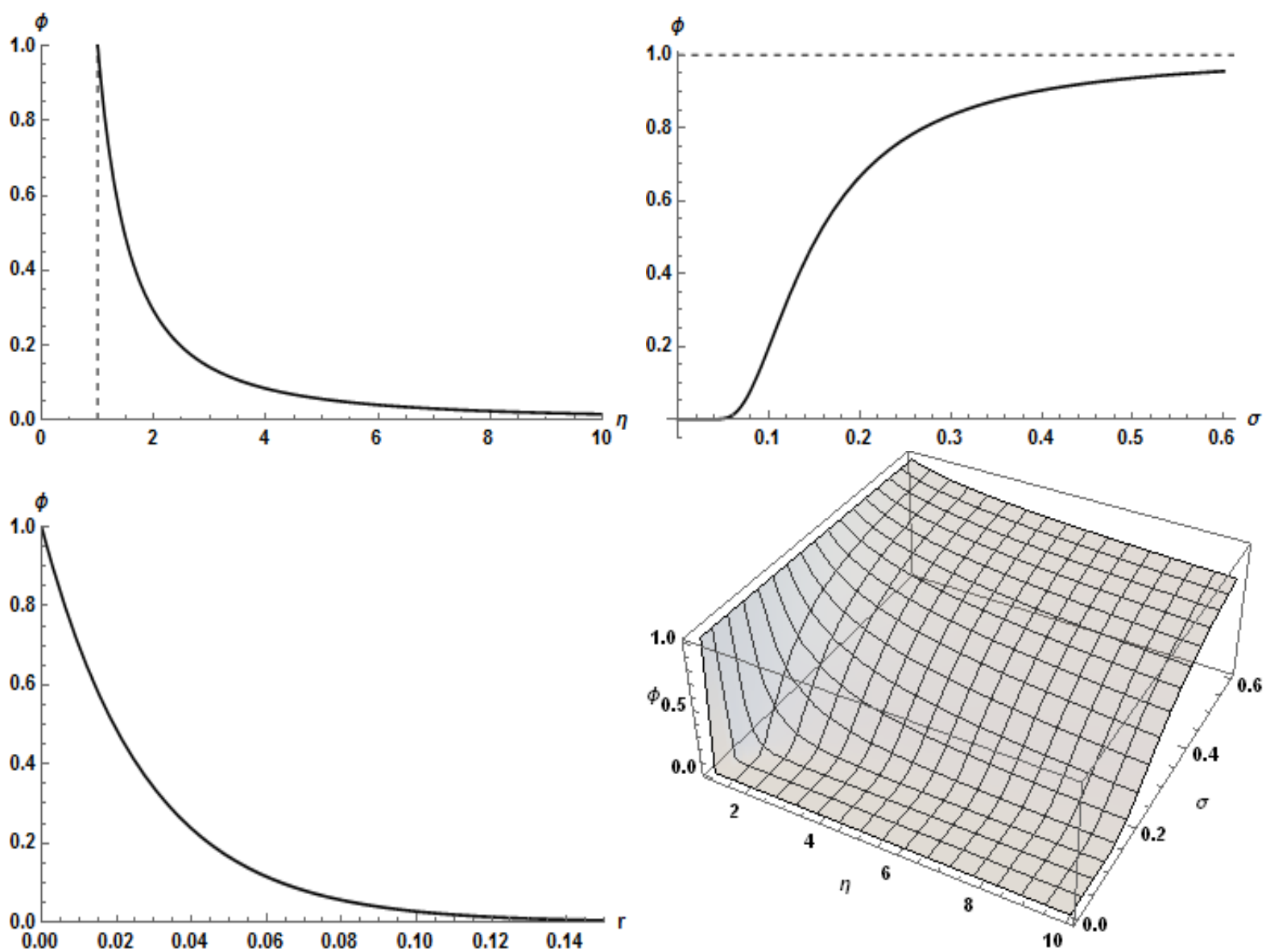

Figure 1. Social risk ratio. The plots of this figure respectively display the social risk ratio $(\varphi)$ as a function of the safety social ratio $(\eta)$ for an interest rate of $2 \%$ and a volatility of $15 \%$; as a function of volatility for a safety social ratio of 1.5 and an interest rate of $2 \%$; as a function of the interest rate for a safety social ratio of 1.5 and a volatility of $15 \%$, and, finally, in the three-dimensional plot, as a function of the safety social ratio for values from 1 to 10 , volatility from 0 to $60 \%$ and a fixed interest rate of $2 \%$. 
corporate tax rate and $\zeta$ the coefficient that measures how many monetary units of CSR Capital the expense has created. This means that the direct net present value $(N P V)$ created by $X$ is $X(\zeta-1)$. For this reason, we call $\zeta$ value creation factor. To obtain the whole value created by the expense, we have also to take into account the tax savings $(\tau X)$ and the reduction in the present value of the social failure costs $(\nabla S F)$ generated by the expense. Recalling (2), the latter can be expressed as:

$$
\nabla S F=S^{*}\left[\left(\frac{S}{S_{c r}}\right)^{\frac{-2 r}{\sigma^{2}}}-\left(\frac{S+\zeta X}{S_{c r}}\right)^{\frac{-2 r}{\sigma^{2}}}\right]
$$

Then, the $N P V$ of this expense is:

$$
N P V(X)=X(\zeta-1)+\tau X+S^{*}\left[\left(\frac{S}{S_{c r}}\right)^{\frac{-2 r}{\sigma^{2}}}-\left(\frac{S+\zeta X}{S_{c r}}\right)^{\frac{-2 r}{\sigma^{2}}}\right]
$$

Dividing both sides of (5) by the critical value of the social capital, we can express these equations in terms of ratios which facilitates its analysis. Denoting by $n p v$ the quotient $N P V / S_{c r}$, by $x$ the proportion of the social expense under analysis over the critical value of the social capital, i.e., $X / S_{c r}$ and by $v$ the ratio $S^{*} / S_{c r}$, we have:

$$
n p v(x)=x(\zeta+\tau-1)+v\left[\eta^{\frac{-2 r}{\sigma^{2}}}-(\eta+\zeta x)^{\frac{-2 r}{\sigma^{2}}}\right]
$$

This equation enables to obtain, applying numerical methods, the values of $\zeta$ that, for giving values of the other variables, equate the npv ratio to zero, i.e. the minimum values of $\zeta$ that do not destroy value ${ }^{3}$. The usefulness of this result lies in the fact that it enables to know to which extent tax savings and the reduction in the present value of social failure costs compensate the negative impact on corporate $N P V$ due to a social expense that, according to the actual perspectives, may reduce corporate value by itself. Table 2 presents a simulation analysis for the minimum values of the value creation factor $\zeta$ that correspond to the values of the other variables shown in the table. Table 3 complements Table 2 by breaking down a nil effective npv into the pure, and negative, pure npv, tax savings and the savings in the present value of social failure costs. All these variables are expressed as ratios.

Figure 2 shows a conceptual map of the article.

\section{Conclusions}

\begin{tabular}{|c|c|c|c|c|c|c|c|}
\hline$x$ & 0.01 & 0.05 & 0.1 & 0.15 & 0.2 & 0.25 & 0.5 \\
\hline \multicolumn{8}{|l|}{$\eta$} \\
\hline 1 & 0.191278 & 0.192763 & 0.194644 & 0.196553 & 0.198488 & 0.200452 & 0.210687 \\
\hline 1.1 & 0.230228 & 0.232033 & 0.234315 & 0.236625 & 0.238963 & 0.241329 & 0.25357 \\
\hline 1.25 & 0.288046 & 0.290222 & 0.292963 & 0.295726 & 0.29851 & 0.301314 & 0.315613 \\
\hline 1.5 & 0.376016 & 0.378438 & 0.381465 & 0.384491 & 0.387516 & 0.390537 & 0.405547 \\
\hline 2 & 0.50451 & 0.506471 & 0.508895 & 0.511289 & 0.513651 & 0.515982 & 0.527161 \\
\hline
\end{tabular}

Social risk, understood as the union of hazards generated by environmental and social sustainability, fuels CSR. This entitles CSR to be regarded as the outcome of combining corporate ethics and social risk. When making

$r=0.02 ; \sigma=0.15 ; \tau=0.30 ; v=1.5$

\footnotetext{
${ }^{3}$ In order to obtain the minimum value of $\zeta$, i.e. the value of $\zeta$ that equates $n p v$ to 0 , we have to take into account that for $\zeta=0$ the $n p v$ becomes equal to $x(\tau-1)$. This value is negative because $\tau$, the tax rate, obviously must be lower than the $100 \%$. The function of $n p v$ is montone increasing in $\zeta$ (positive first derivative for nonnegative values of $\zeta$, which is equal to $x+x \gamma(x \zeta+\eta)^{-1-\gamma} v$, where $\left.\gamma=2 r / \sigma^{2}\right)$. Thus, the value of $\zeta$ that equates $n p v$ to 0 is unique. Then, we can obtain this value by solving Equation (6) for $\zeta$, which can be done by numerical methods. The values of $\zeta$ in Table 2 have been calculated through the command NSolve of Mathematica software.
} 
Table 3. Analyzing the minimum value creation factor $\zeta$.

\begin{tabular}{cccccc}
\hline$\eta$ & $\zeta$ & Pure $n p v$ & Tax savings & PV social costs savings & Effective $n p v$ \\
\hline 1 & 0.200452 & -0.19989 & 0.075 & 0.124887 & 0 \\
1.1 & 0.241329 & -0.18967 & 0.075 & 0.114668 & 0 \\
1.25 & 0.301314 & -0.17467 & 0.075 & 0.099671 & 0 \\
1.5 & 0.390537 & -0.15237 & 0.075 & 0.077366 & 0 \\
2 & 0.515982 & -0.121 & 0.075 & 0.046005 & 0 \\
\hline
\end{tabular}

This table shows the detailed calculations embedded in Table 2 for $x=0.25$. The pure $n p v$ corresponds to the term $x(\zeta-1)$. Tax savings express $x \tau$. The present value $(\mathrm{PV})$ of social costs savings is $v\left[\eta^{\frac{-2 r}{\sigma^{2}}}-(\eta+\zeta x)^{\frac{-2 r}{\sigma^{2}}}\right]$.

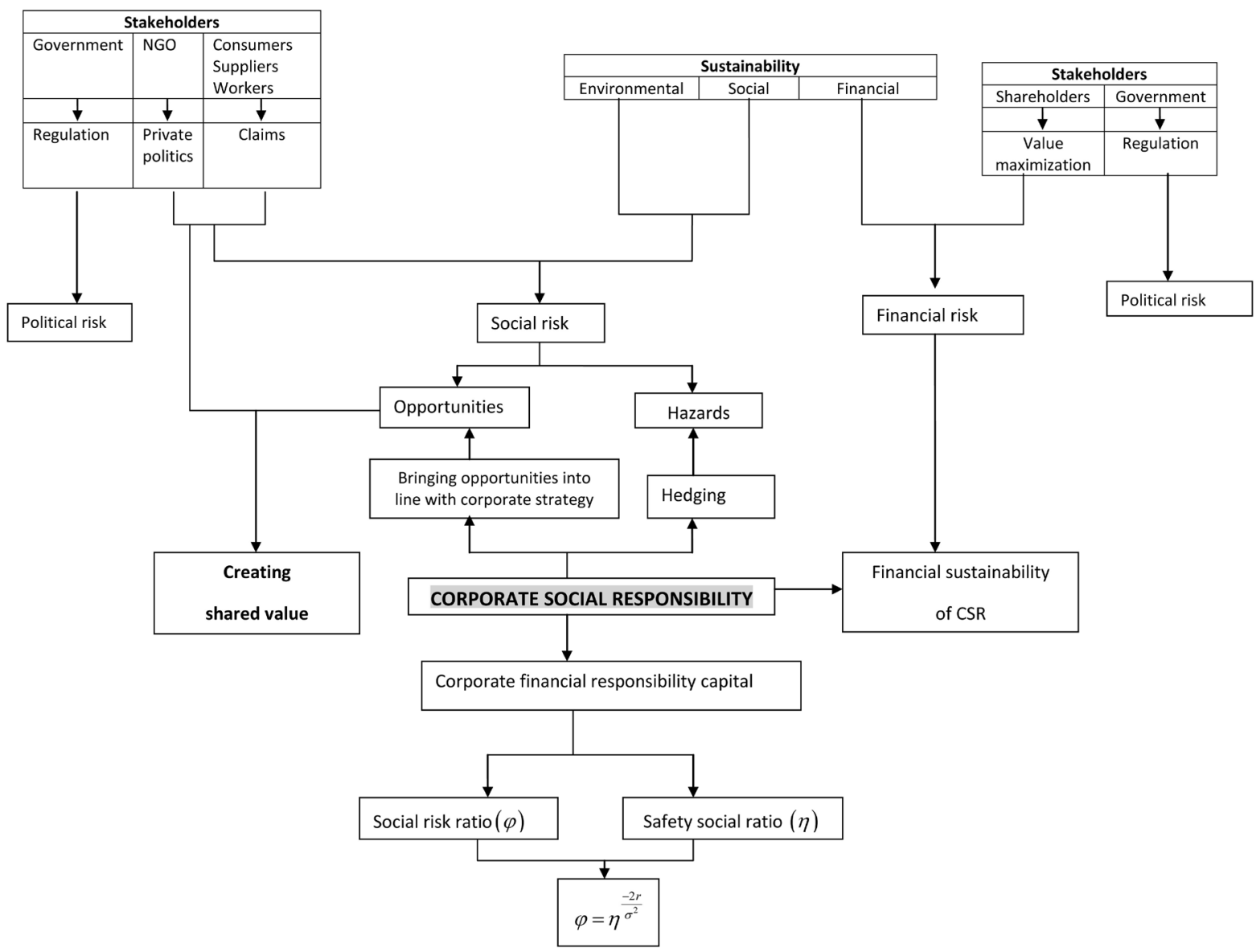

Figure 2. Corporate social responsibility from the viewpoint of risk conceptual map.

CSR decisions, corporations must be aware that they are managing the social risk and, at the same time, that CSR decisions also involve financial risk, which mainly means that CSR projects must be financially sustainable on themselves or, at least, for the corporation as a whole. The management of social risk requires a twofold analysis. On one hand, the environmental and social sustainability of ordinary corporate decisions must be systematically examined. On the other hand, CSR decisions must be evaluated taking into account the use they made of the corporate know-how and the possible participation of stakeholders in them in order to create shared value. Social risk hardly admits a specific hedging. Nevertheless, applying Bernsteins's piece of advice on risk management and building up a positive social image can be regarded as a reasonable hedge against unexpected hazards. The social failure model that, following Leland's bankruptcy model, we have developed, analytically relates some of the central variables of social risk. Although they are difficult to quantify, having these variables 
in a formula facilitates a more precise thinking and, in addition, it opens the way to simulation.

All in all, social risk, as risk in general, is not only a source of hazards but a source of opportunities that requires a proper and clever management with ethics in mind. As Bernstein (1998, pp. 336-337) says, the thinkers on risk from Pascal to Markowitz have transformed the perception of risk from chance of loss into opportunity for gain, from fate and original design to sophisticated, probability-based forecasts of the future, and from helplessness to choice. Social risk is a force that leads to transform self-interest into shared value.

\section{References}

[1] Bernstein (1998) Against the Gods. 2nd Edition, John Wiley \& Sons, New York.

[2] United Nations (2014) UN Global Compact.

http://www.unglobalcompact.org/AboutTheGC/index.html

[3] United Nations (2011) Guiding Principles on Business and Human Rights. http://daccess-dds-ny.un.org/doc/UNDOC/GEN/G11/121/90/PDF/G1112190.pdf?OpenElement

[4] McCorquodale, R. (2009) Corporate Social Responsibility and International Human Rights Law. Journal of Business Ethics, 87, 385-400. http://dx.doi.org/10.1007/s10551-009-0296-5

[5] Lee, D.E. and Lee E.J. (2010) Human Rights and the Ethics of Globalisation. Cambridge University Press, Cambridge. http://dx.doi.org/10.1017/CBO9780511778148

[6] Credit Suisse (2014) Risk Categories. https://www.credit-suisse.com/media/cc/docs/investors/risk/risk.pdf

[7] Soprano, A., Crielaard, B., Piacenza, F. and Ruspantini, D. (2009) Measuring Operational and Reputational Risks. John Wiley \&Sons, Chichester.

[8] Stansfield, G. (2006) Some Thoughts on Reputation and Challenges for Global Financial Institutions. Geneva Papers on Risk \& Insurance, 31, 470-479. http://dx.doi.org/10.1057/palgrave.gpp.2510087

[9] Bekefi, T., Jenkings, B. and Kytle, B. (2006) Social Risk as Strategic Risk. Corporate Social Responsibility Initiative, Working Paper No. 30. John F. Kennedy School of Government, Harvard University, Cambridge, MA.

[10] Orlitzky, M. and Benjamin, J. D. (2001) Corporate Social Performance and Firm Risk: A Meta-Analytic Review. Business and Society, 40, 369-396. http://dx.doi.org/10.1177/000765030104000402

[11] Baron, D.P. (2001) Private Politics, Corporate Social Responsibility and Integrated Strategy. Journal of Economics and Management Strategy, 10, 7-45. http://dx.doi.org/10.1162/105864001300122548

[12] Schepers, D.H. (2006) The Impact of NGO Network Conflict on the Corporate Social Responsibility Strategies of Multinational Corporations. Business and Society, 45, 282-299. http://dx.doi.org/10.1177/0007650306289386

[13] Kitzmueller, M. and Shimshack, J. (2012) Economic Perspectives on Corporate Social Responsibility. Journal of Economic Literature, 50, 51-84. http://dx.doi.org/10.1257/jel.50.1.51

[14] Baron, D.P. (2009) A Positive Theory of Moral Management, Social Pressure, and Corporate Social Performance. Journal of Economics \& Management Strategy, 18, 7-43. http://dx.doi.org/10.1111/j.1530-9134.2009.00206.x

[15] Bekefi, T. and Epstein, M.J. (2008) Transforming Social and Environmental Risks into Opportunities. Strategic Finance, 89, 42-47.

[16] Porter, M.E. and Kramer, M.R. (2011) The Big Idea: Creating Shared Value. Harvard Business Review, 89, 2-17.

[17] Porter, M.E. and van der Linde, C. (1995) Green and Competitive: Ending the Stalemate. Harvard Business Review, 73, 120.

[18] Porter, M.E. and Kramer, M.R. (2006) Strategy \& Society: The Link between Competitive Advantage and Corporate Social Responsibility. Harvard Business Review, 84, 78-85.

[19] Pfitzer, M., Bockstette, V. and Stamp, M. (2013) Innovating for Shared Value. Harvard Business Review, 91, $100-107$.

[20] Porter, M.E. and Kramer, M.R. (1999) Philanthropy’s New Agenda: Creating Value. Harvard Business Review, 77, 121-130.

[21] Godfrey, P.C., Merrill, C.B. and Hansen, J.M. (2009) The Relationship between Corporate Social Responsibility and Shareholder Value: An Empirical Test of the Risk Management Hypothesis. Strategic Management Journal, 30, 425445. http://dx.doi.org/10.1002/smj.750

[22] Gaultier-Gaillard, S. and Louisot, J. (2006) Risks to Reputation: A Global Approach. Geneva Papers on Risk \& Insurance, 31, 425-445. http://dx.doi.org/10.1057/palgrave.gpp.2510090

[23] Fombrun, C.J., Gardberg, N.A. and Barnett, M.L. (2000) Opportunity Platforms and Safety Nets: Corporate Citizenship and Reputational Risk. Business and Society Review, 105, 85-106. http://dx.doi.org/10.1111/0045-3609.00066 
[24] Fombrun, C.J. (2005) Building Corporate Reputation through CSR Initiatives: Evolving Standards. Corporate Reputation Review, 8, 7-11. http://dx.doi.org/10.1057/palgrave.crr.1540235

[25] Benabou, R. and Tirole, J. (2010) Individual and Corporate Social Responsibility. Economica, 77, 1-19. http://dx.doi.org/10.1111/j.1468-0335.2009.00843.x

[26] Srivastava, R.K., McInish, T.H., Wood, R.A. and Capraro, A.J. (1997) Part IV: How Do Reputations Affect Corporate Performance?: The Value of Corporate Reputation: Evidence from the Equity Markets. Corporate Reputation Review, 1, 61-68. http://dx.doi.org/10.1057/palgrave.crr.1540018

[27] Ponzi, L.J., Fombrun, C.J. and Gardberg, N.A. (2011) RepTrak ${ }^{\mathrm{TM}}$ Pulse: Conceptualizing and Validating a Short-Form Measure of Corporate Reputation. Corporate Reputation Review, 14, 15-35. http://dx.doi.org/10.1057/crr.2011.5

[28] Bekefi, T. and Epstein, M.J. (2008) Measuring and Managing Social and Political Risk. Strategic Finance, 89, 33-41.

[29] Donaldson, J.P. and Danthine, J.B. (2005) Intermediate Financial Theory. 2nd Edition, Elsevier, San Diego.

[30] Tapiero, C.S. (2010) Risk Finance and Asset Pricing: Value, Measurements, and Markets. John Wiley \& Sons, Hoboken.

[31] Leland, H.E. (1994) Corporate Debt Value, Bond Covenants, and Optimal Capital Structure. Journal of Finance, 49, 1213-1252. http://dx.doi.org/10.1111/j.1540-6261.1994.tb02452.x 
Scientific Research Publishing (SCIRP) is one of the largest Open Access journal publishers. It is currently publishing more than 200 open access, online, peer-reviewed journals covering a wide range of academic disciplines. SCIRP serves the worldwide academic communities and contributes to the progress and application of science with its publication.

Other selected journals from SCIRP are listed as below. Submit your manuscript to us via either submit@scirp.org or Online Submission Portal.
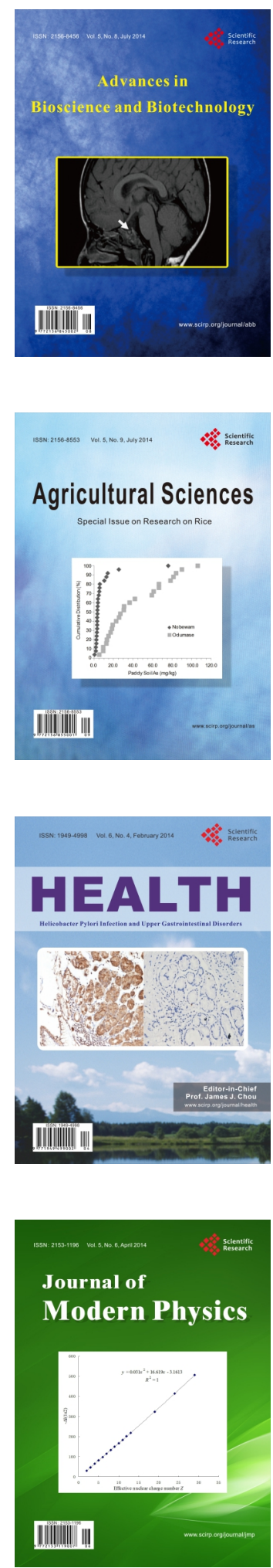
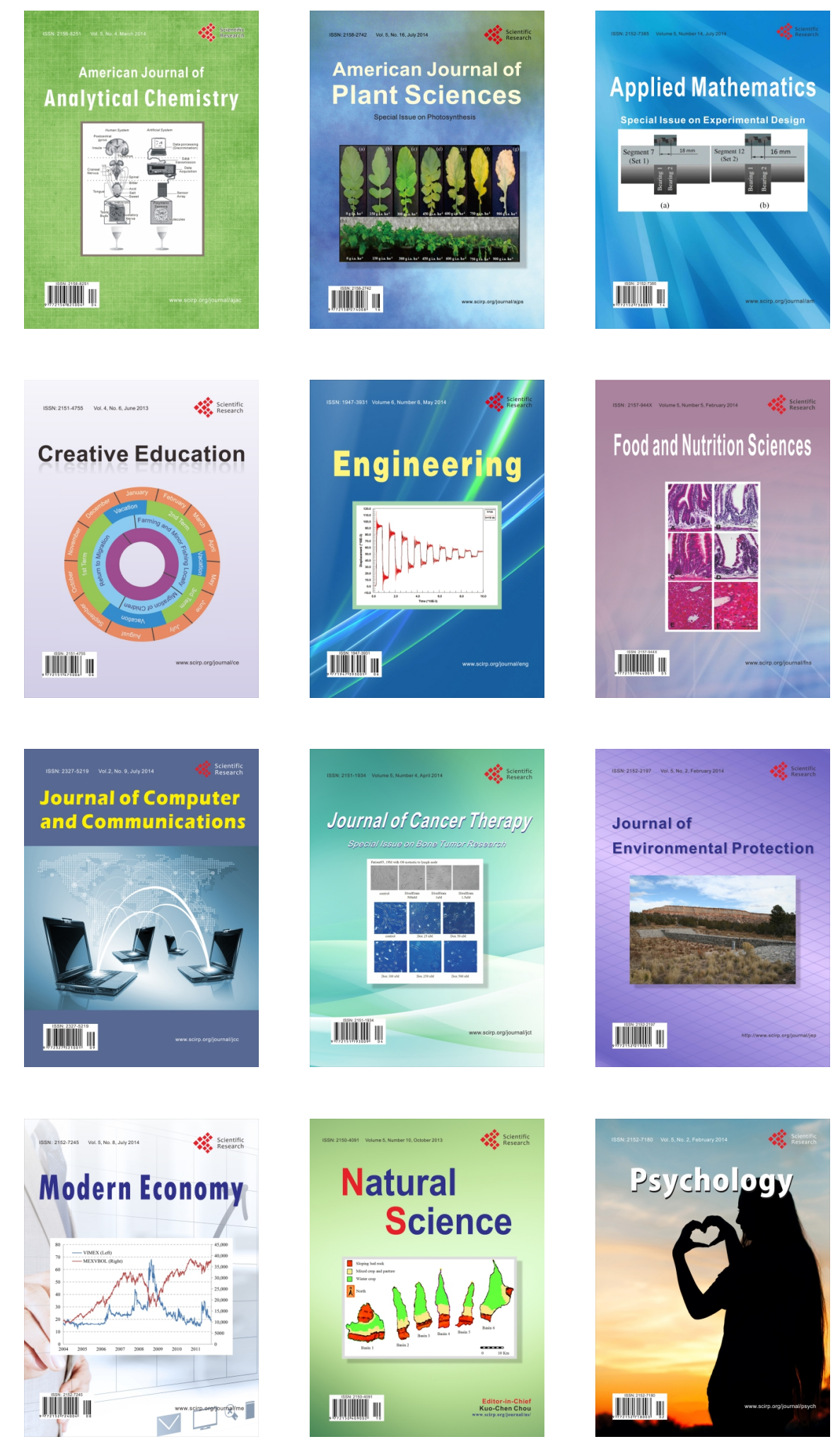